\title{
Feeding and Life History of Alabama argillacea (Lepidoptera: Noctuidae) on Cotton Cultivars Producing Colored Fibers
}

Author(s): A.R.B. Nascimento, F. S. Ramalho, T. L. Azeredo, F. S. Fernandes, J. L. Nascimento Júnior, C.A.D. Silva and J. B. Malaquias

Source: Annals of the Entomological Society of America, 104(4):613-619. 2011.

Published By: Entomological Society of America

DOI: $10.1603 / \mathrm{AN} 10195$

URL: http://www.bioone.org/doi/full/10.1603/AN10195

BioOne (www.bioone.org) is an electronic aggregator of bioscience research content, and the online home to over 160 journals and books published by not-for-profit societies, associations, museums, institutions, and presses.

Your use of this PDF, the BioOne Web site, and all posted and associated content indicates your acceptance of BioOne's Terms of Use, available at www.bioone.org/page/terms of use.

Usage of BioOne content is strictly limited to personal, educational, and non-commercial use. Commercial inquiries or rights and permissions requests should be directed to the individual publisher as copyright holder. 


\title{
Feeding and Life History of Alabama argillacea (Lepidoptera: Noctuidae) on Cotton Cultivars Producing Colored Fibers
}

\author{
A.R.B. NASCIMENTO, F. S. RAMALHO ${ }^{1}{ }^{\text {T. }}$ L. AZEREDO, F. S. FERNANDES, \\ J. L. NASCIMENTO JÚNIOR, C.A.D. SILVA, AND J. B. MALAQUIAS
}

Biological Control Unit/Embrapa Algodão, Av. Osvaldo Cruz, 1143 Campina Grande, Paraíba, 58107-720, Brazil

Ann. Entomol. Soc. Am. 104(4): 613-619 (2011); DOI: 10.1603/AN10195

\begin{abstract}
Quantitative analysis of the consumption and use by herbivore pest's of the host plant is a common tool used for studying the interaction between insects and plants. Our goals were to quantify cotton leafworm, Alabama argillacea (Hübner) (Lepidoptera: Noctuidae), larval consumption rate in three cotton, Gossypium hirsutum L., cultivars that produce colored cotton fibers, and the effects of the consumption rate on A. argillacea pupal weight in greenhouse conditions. Larvae consumed a maximum of $0.69-1.03 \mathrm{~g}$ of leaf tissue over a $24-\mathrm{h}$ period in all cultivars tested. Total consumption by A. argillacea larvae was highest when fed with 'BRS 200 ' leaves $(2.89 \mathrm{~g})$ and the lowest when fed with leaves from 'BRS Safira' ( $2.26 \mathrm{~g})$. The regression analysis showed significant relationships between the quantity of leaf tissue consumed and pupal weights for each cotton cultivar. $A$. argillacea larvae fed on BRS 200 demonstrated a longer developmental period (14.84 d) than larvae fed on 'BRS Rubi' leaves (11.62 d) or BRS Safira (11.14 d). We concluded that BRS Safira presents the best quality food source for A. argillacea, BRS 200 is the worst, and BRS Rubí is intermediate. The longer developmental times of A. argillacea on BRS 200 may allow longer windows of opportunity for the use of biological control agents to reduce the damage caused by this pest and also would complete less generations per phenological cycle of the cotton crop.
\end{abstract}

KEY WORDS Gossypium hirsutum, consumption rates, feeding, growth index, biology

Natural colored cotton is ecologically friendly, because it reduces the dyeing stage in industrial production in which frequently and perhaps incorrectly used chemicals can be damaging to human health (Horstmann 1995). Cotton (Gossypium hirsutum L.) cloth production costs are reduced by leaving out these stages, diminishing water and energy expenditure, as well as reducing the quantity of waste to be treated. The colorants used for dyeing this cloth are harmful to human health and very often carcinogenic (Horstmann 1995). As such, development of cotton cultivars that produce colored fibers is an alternative for recuperating the cotton agribusiness in northeastern Brazil.

One of the factors limiting cotton cultivation in Brazil is the attack by pests. One of them, the cotton leafworm, Alabama argillacea (Hübner) (Lepidoptera: Noctuidae), is the main defoliator of this crop (Ramalho 1994). A. argillacea is a native species of the central and south regions of America, found in nearly all cotton-growing regions from the north of United States to the north of Argentina (Carvalho 1981).

In Brazil, where this crop is planted, A. Argillacea may infest cotton in one stage of its phenological development. In the south central region of Brazil, it

${ }^{1}$ Corresponding author, e-mail: ramalhohvv@globo.com. is considered as a late pest but in the north, except in Bahia, it attacks early stages but can sporadically occur at the end of crop. High densities of this pest can cause a negative impact in cotton production. In Brazil, losses caused by A. argillacea vary from 21 to $35 \%$ of cotton lint production (Ramalho 1994).

A. argillacea has been basically controlled with insecticides (Ramalho 1994). The high socioeconomic cost of insecticide use (Marchini 1976) has made it necessary to look for efficient, economically viable and ecologically correct alternatives (Ramalho 1994). A group for integrated pest management has been set up, which aims to bring together knowledge from environmental areas to population dynamics of the target species, in an effort of using the most appropriate methods and techniques possible, to maintain pest populations at levels from damaging economically.

Development of efficient strategies to control A. argillace a requires the understanding of its biological relationship with the host plant. Therefore, an important component is understanding the host's susceptibility to the pest. Quantitative analysis of pest's consumption and use of the host plant is a common tool used in studying the interaction between insects and plants (Scriber and Slanky 1981). Variables that describe the insect's food consumption, how well this 
food is converted into biomass, and the rate at which the insect grows can bring us to understand how a certain species of insect responds to variations in host plant susceptibility. Studying the feeding effect on the insect's biology is of great importance in understanding the host's influence in this pest and may help in evaluating the severity of injury caused to the crop by the insect. This information can be used in developing a much better pest control strategies. Studies have evaluated the effects of host plants on the potential of A. argillacea population growth (Montandon et al. 1986, Ferreira and Lara 1999, Santos and Boiça 2001) or quantified the impact of this pest on cotton production reduction (Marchini 1976). However, this information about A. argillacea feeding is incomplete, especially for cotton that produces colored fibers. Therefore, were quantified the A. argillace a larval consumption rate in three of these cotton cultivars and the effects of the consumption rate on A. argillacea pupal weight. Understanding the differences in food quality between the three cotton cultivars could have practical implications in managing $A$. argillacea in this crop's ecosystem.

\section{Materials and Methods}

Cotton Cultivar and Growth Conditions. We used three cotton cultivars that produce colored fibers: 'BRS Safira', 'BRS Rubí, and 'BRS 200'. BRS 200 is a bulk hybrid produced by mixing equal parts of seeds from strains of CNPA 92 1139, CNPA 94 362, and CNPA 95653 perennial cotton that have light brown lint and tough, fibrous leaves, whereas BRS Safira has tender leaves with little fiber and was produced by crossing upland cotton introduced from the United States, which exhibits a dark brown-colored lint, with the CNPA 87-33 cultivar, which has good quality white lint. BRS Rubi has tender leaves with little fiber and was produced by crossing upland cotton with CNPA $7 \mathrm{H}$, which has good quality white lint. All three cultivars were planted in plastic pots $(20 \mathrm{~cm}$ in diameter and $30 \mathrm{~cm}$ in height) in a greenhouse. The temperature was maintained at $28 \pm 2^{\circ} \mathrm{C}$ and humidity relative to $70 \pm 10 \%$ under a photoperiod of $12: 12$ (L:D) h. One hundred and fifty plants of each cotton cultivar were distributed randomly in greenhouses and randomly repositioned once a week to minimize the position effects. Fertilizers were not applied as base and neither during cotton growth period.

Insects. A. argillacea eggs were obtained from the Unidade de Controle Biológico da Embrapa Algodão (Embrapa Cotton Biological Control Unit), and hatched larvae were kept in an incubator chamber $\left(25^{\circ} \mathrm{C}, 70 \pm 5 \% \mathrm{RH}\right.$, a photoperiod of $12: 12$ [L:D] h at $40,000 \mathrm{LX}$ radiation produced by $40-\mathrm{W}$ fluorescent lamps), and they were reared on cotton leaves (CNPA $7 \mathrm{H})$.

Feeding Tests. When the plants produced eight to 10 leaves (20-30 d old). Fully grown, undamaged leaves were taken from the upper two thirds of the plant and given as food in the growth chamber to the recently hatched larvae under conditions described above. A randomized block design was used, feeding larvae with each of the three cotton cultivars in 16 replications, and each experimental unit composed of 10 larvae. The larvae were kept individually in plastic containers ( $80 \mathrm{~mm}$ in diameter). The lid had a circular piece of nylon for ventilation. Leaves were cut, weighed, and the stem ends were covered with damp cotton to avoid drying out. After $24 \mathrm{~h}$, feces were removed from the leaves, and the leaves were weighed again. The pots were cleaned and new leaves were weighed and given to the larvae. This procedure was carried out every day for each larva until the larvae stopped feeding, that is, until they entered the prepupae stage. The experimental units were kept in an incubator chamber as described previously.

To determine leaf weight loss caused by evaporation, previously weighed leaves were exposed to the same conditions for a similar period of time and then reweighed. Larval daily consumption was estimated by subtracting the weight of the remaining leaf tissue from the weight of the control leaf minus the evaporation factor.

Growth and Developmental Indexes. Larval developmental time, pupal weight, and survival rate were recorded. A feeding index was calculated by dividing mean pupal weight by mean weight of leaf tissue consumed for each cotton cultivar. The growth index (GI) was calculated as the ratio between the percentage of adults emerged and the duration of the immature period (larval and pupal stages) (Sétamou et al. 1999).

Data Analysis. Analysis of variance (ANOVA) (SAS Institute 2006) was used to analyze the cultivar effects on larva consumption and biological parameters. Means of cotton cultivar for each variable were separated using the Student-Newman-Keuls test $(P=$ 0.05) (SAS Institute 2006) when significant $F$ values were obtained. For each cotton cultivar, linear or quadratic regression analysis was used to examine the relationship between the amount of diet consumed and pupal weight. For each type of relationship, parallel line analysis was applied to compare the regressions of the three cotton cultivars by using the PROC MIXED procedure SAS (Littell et al. 1997, Sétamou et al. 1999). First, homogeneity of the regression coefficients between the different cotton cultivars was tested, and whenever the slopes were homogeneous, the least square (LS) means were compared using multiple $t$-tests (Littell et al. 1997).

\section{Results}

Larval Consumption Rates. Alabama argillacea larva consumed a maximum of 0.69 to $1.03 \mathrm{~g}$ of leaf tissue over a 24 -h period in all cultivars tested (Fig. 1). Peaks in consumption occurred at 10,11 , and $15 \mathrm{~d}$ in BRS Rubi, BRS Safira, and BRS 200, respectively. The consumption rates rose in BRS Safira up to pupation but not in BRS Rubi and BRS 200, for which the growth rates varied. Total consumption by $A$. argillacea larvae was highest when fed with BRS 200 leaves (2.89 g) and 


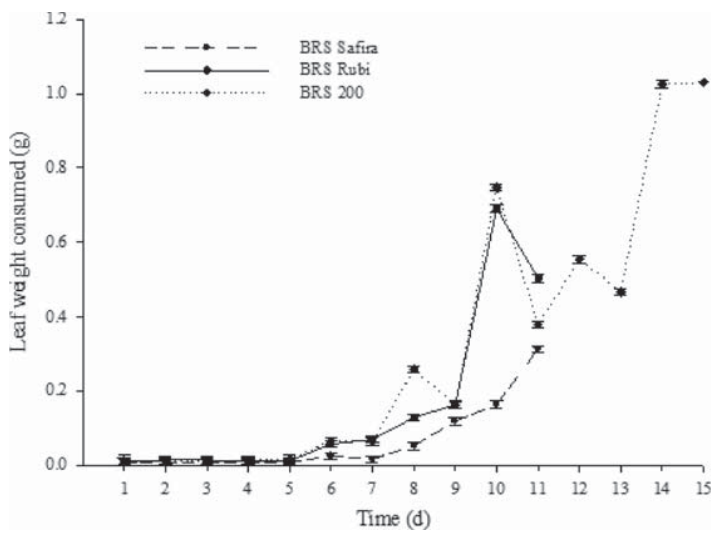

Fig. 1. Mean weight of leaf tissue (grams of fresh weight) of three cotton cultivars with colored fibers consumed per larva of A. argillacea measured at 24-h intervals (bars indicate $\mathrm{SE})$.

the lowest when fed with leaves from BRS Safira (2.26 g) $\left(F_{2,30}=30.87 ; P<0.0001\right)$ (Fig. 2).

Effects of Consumption on Pupae Weights. The regression analysis showed significant relationships between the amount of leaf tissue consumed and the pupal weights for each cotton cultivar (BRS Safira: $\mathrm{y}=-1.06+0.73 \mathrm{x}-0.11 \mathrm{x}^{2}, F_{2,13}=41.47, P<0.0001$, $R^{2}=0.86$; BRS Rubi: $\mathrm{y}=4.20-335 \mathrm{x}+0.67 \mathrm{x}^{2}, F_{2,13}=$ 615.76, $\left.P<0.0001, R^{2}=0.98\right)$; and BRS 200: $\mathrm{y}=$ $\left.-0.04+0.04 \mathrm{x}, F_{1,14}=414.74, P<0.0001, R^{2}=0.97\right)$ (Fig. 3). The parallel line regression analyses also revealed significant relationships between total weight of food consumed by larvae and pupal weight (Table 1). The amount of variation explained ranging from $83 \%$ on BRS Safira to $98 \%$ on BRS Rubí. Mean pupal weight was highest on BRS Safira $(0.134 \mathrm{~g})$ than on BRS Rubi (0.091 g) or BRS $200(0.056 \mathrm{~g})\left(F_{2,30}=\right.$ 549.71; $P<0.0001$ ) (Fig. 4A). Parallel line regression

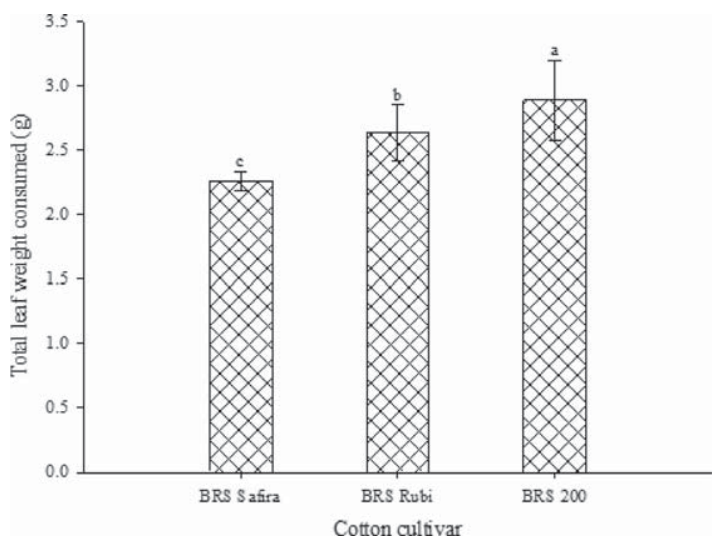

Fig. 2. Total weight (grams of fresh weight) of leaf tissue of three cotton cultivars producing colored fibers consumed per larva of A. argillacea $\left(F_{2,30}=30.87 ; P<0.0001\right)$. Error bars indicate $\mathrm{SE}$. Letters above the bars indicate significant differences between cultivars by the Student-Newman-Keuls test $(P=0.05)$.
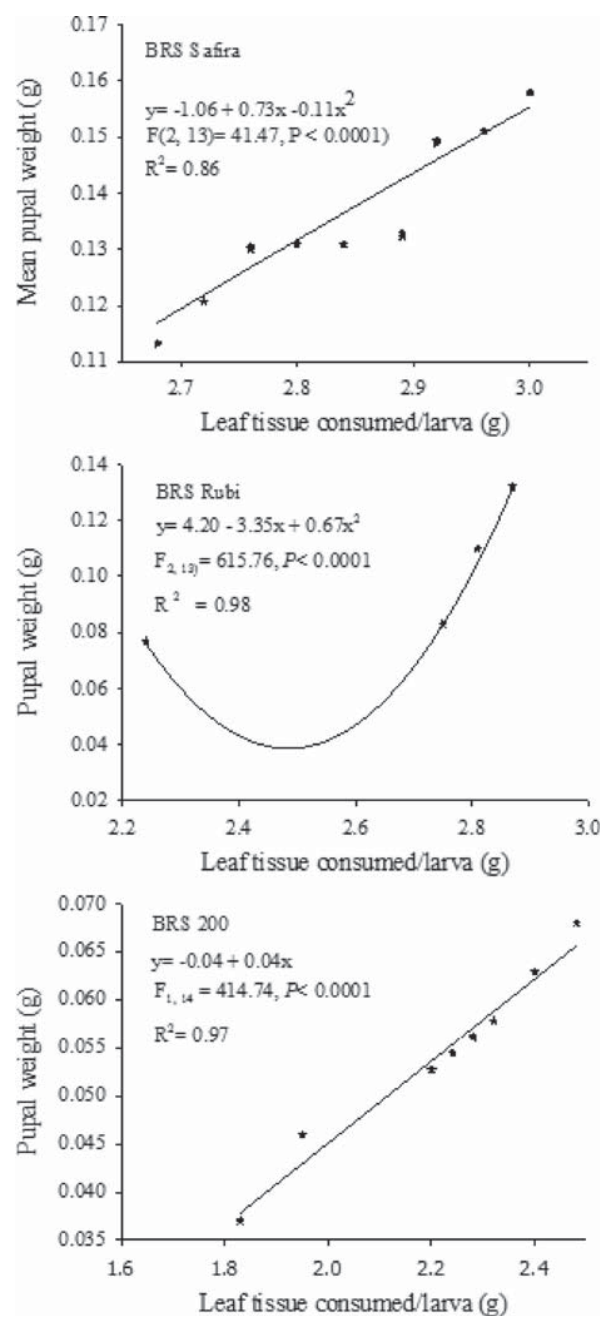

Fig. 3. Relationships between pupal weight (grams of fresh weight) of A. argillacea and leaf tissue of three cotton cultivars producing colored fibers (BRS Safira, BRS Rubi, and BRS 200) consumed by A. argillacea larvae.

analyses showed heterogeneity of the regression slopes between cultivars as was shown by the significant interaction between the dependent and the independent variables in the covariance analysis $\left(F_{2,14}=8.98 ; P<0.015\right)$. The highest pupal weight gain per unit of food consumed $(1.34 \mathrm{~g} / \mathrm{g})$ was obtained on BRS Rubí leaves $\left(F_{2}{ }_{14}=8.98 ; P<0.012\right)$, whereas each unit of BRS 200 consumed by larvae produced only $0.04 \mathrm{~g}$ of pupal weight gain (Fig. 3). However, the least square means comparison showed that BRS Safira had greater effect on A. argillacea pupal weight than BRS $200\left(t_{25}=5.98, P<0.012\right)$. The feeding rate was higher in BRS Safira than in BRS Rubi and BRS 200 (Fig. 4B). However, BRS 200 presented the lowest feeding rates that the other cultivars $\left(F_{2,30}\right.$ $=379.98 ; P<0.0001$ ) (Fig. 4B).

Effects of Cultivar on Development and Survival. A. argillacea leafworms that fed on BRS 200 cotton leaves $(14.84 \mathrm{~d})$ demonstrated a longer developmental pe- 
Table 1. Slopes and intercepts of regressions and their SEs

\begin{tabular}{|c|c|c|c|c|c|c|c|}
\hline \multirow{2}{*}{ Cotton cultivar } & \multirow{2}{*}{ Model } & \multicolumn{4}{|c|}{ Leaf tissue consumed vs pupal wt } & \multirow{2}{*}{$t$ (slope) } & \multirow{2}{*}{$P$} \\
\hline & & Slope & SE & Intercept & $\mathrm{SE}$ & & \\
\hline BRS Safira & Quadratic & 0.221 & 0.012 & 0.731 & 0.208 & 5.16 & 0.0002 \\
\hline BRS Rubi & Quadratic & 1.341 & 0.025 & 4.20 & 0.154 & 27.49 & 0.0001 \\
\hline BRS 200 & Linear & 0.042 & 0.002 & -0.043 & 0.004 & 20.37 & 0.0001 \\
\hline
\end{tabular}

riod than leafworms fed on BRS Rubi leaves (11.62 d) or BRS Safira leaves $(11.14 \mathrm{~d})\left(F_{2,30}=340.29 ; P<\right.$ 0.0001 ) (Table 2). Cotton leafworm survival rate when fed on cotton leaves from BRS Safira (94.53\%) or BRS Rubi $(94.53 \%)$ was higher than that of cotton leafworm larvae that fed on leaves from BRS $200(79.50 \%)$ $\left(F_{2,30}=69.38 ; P<0.0001\right)$ (Table 2). A. argillacea larvae that fed on leaves from cultivars BRS Safira or BRS Rubi showed higher growth rates than those fed with leaves from BRS $200\left(F_{2,30}=121.12 ; P<0.0001\right)$.

\section{Discussion}

Host plants can play an important role in establishing pest insect populations (Saeed et al. 2010), be it in the form of nutrition, providing a satisfactory physiological balance sustaining insect' development
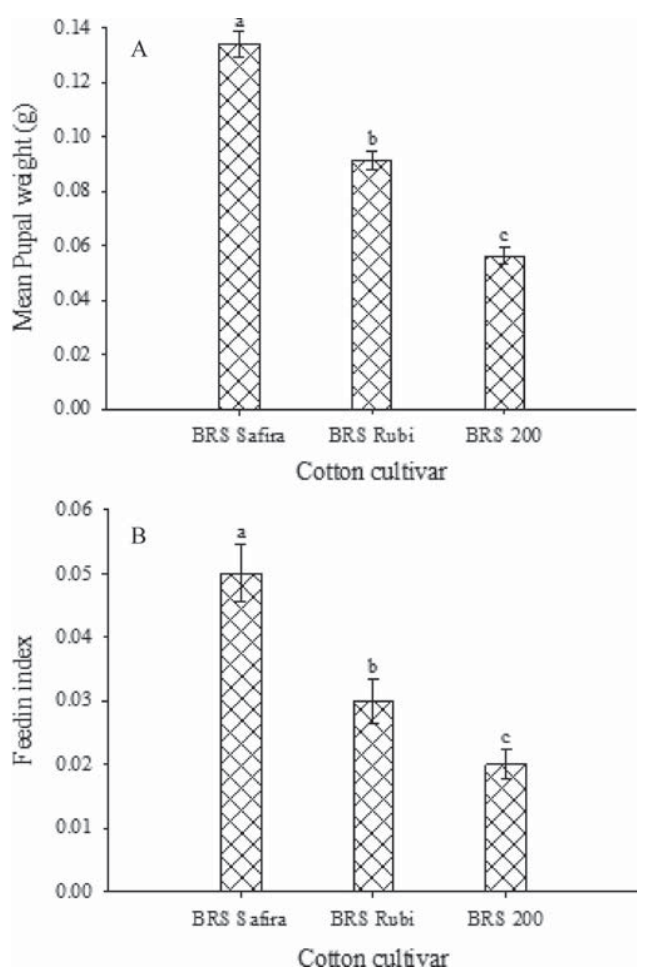

Fig. 4. (A) Mean pupal weights (grams of fresh weight) of A. argillacea for each cotton cultivar producing colored fibers $\left(F_{2,30}=549.71 ; P<0.0001\right)$. (B) Mean feeding index (pupal weight/tissue consumed) $\left(F_{2,30}=379.98 ; P<0.0001\right)$. Error bars indicate SE. Letters above the bars indicate significant differences between cultivars by the Student-Newman-Keuls test $(P=0.05)$.
(Waldbauer 1968) or by adaptive aspects resulting from plant and insect coevolution enabling plant to maintain their defense mechanisms against herbivorous insects (Yamamoto and Fraenkel 1960). Many plants have secondary substances that impede phytophagous insect feeding and oviposition (Yamamoto and Fraenkel 1960, Hsiao and Fraenkel 1968), and there is evidence of substances present in cotton that could impede A. argillacea feeding (Montandon et al. 1986).

The A. argillacea larvae fed on the cotton cultivars with colored fibers showed differences in their feeding pattern. In the first $4 \mathrm{~d}$ of larval development, they showed a similar feeding pattern, regardless of the cultivar (Fig. 1). Young larvae are more selective when choosing food, seeking out the most suitable areas of the leaf (Wier and Boethel 1995), which contain less fiber and they avoid gossypol glands (Parrot et al. 1983). From the fifth day of life onward, their feeding pattern varied according to the cultivar. This was because the second-instar larvae are less selective about food, eating practically any part of the leaf, trying to eat large amounts of food that are, in turn, used for movement, growth and maintaining the homeostatic balance (Parrot et al. 1983). Energy supplements are required for molting, because for ecdysis to occur, a minimum critical mass must be attained so feeding on immature stages tends to supply them with enough energy requirements to reach the middle of each larval stage; from this developmental stage on, these values tend to be reduced, as larvae get closer to ecdysis (Scriber and Slansky 1981). On BRS Safira, cotton leafworm larvae maintained a constant feeding rate, reaching peak consumption at $11 \mathrm{~d}$, whereas feeding oscillated in BRS Rubí, reaching a peak at $10 \mathrm{~d}$, culminating in premature pupation compared with larvae fed on BRS 200 cotton leaves, also with variable consumption rate and peaking at $14 \mathrm{~d}$ (Fig. 1). However, leaves from BRS 200 (2.89 g per larva) were more highly consumed than leaves from BRS Rubí (2.64 g per larva) or BRS Safira (2.26 g per larva) (Fig. 2). This may be explained in part because larvae that fed on BRS Rubi or BRS Safira leaves peaked earlier and stopped feeding at $11 \mathrm{~d}$ (Fig. 1). The low feeding rates on BRS Safira leaves are not the result of the larvae's aversion to the BRS Safira as a host plant. A plausible explanation is that this cultivar has higher nutritional quality for A. argillacea than the other cotton cultivars.

Within each cotton cultivar, weight of the leaf tissue consumed was positively related with pupal weight. Although total larval consumption was lowest on BRS Safira, pupal weight was highest with this treatment $(0.1340 \mathrm{~g})$, compared with $0.0914 \mathrm{~g}$ for BRS Rubí and 
Table 2. Mean values \pm SD of the life history parameters of $A$. argillacea fed on cotton cultivars producing colored fibers

\begin{tabular}{|c|c|c|c|c|}
\hline \multirow{2}{*}{ Life history parameter } & \multicolumn{3}{|c|}{ Cultivar $^{a}$} & \multirow{2}{*}{$F_{2}, 30(P)$} \\
\hline & BRS Safira & BRS Rubi & BRS 200 & \\
\hline Larval development (d) & $11.14 \pm 1.72 \mathrm{a}$ & $11.62 \pm 1.12 \mathrm{a}$ & $14.84 \pm 1.04 \mathrm{~b}$ & $340.29(0.0001)$ \\
\hline Larval survivorship (\%) & $94.53 \pm 10.84 a$ & $94.53 \pm 12.77 \mathrm{a}$ & $79.50 \pm 7.98 b$ & $69.38(0.0001)$ \\
\hline $\mathrm{GI}^{b}$ & $4.81 \pm 1.03 \mathrm{a}$ & $4.67 \pm 1.21 \mathrm{a}$ & $3.14 \pm 0.79 \mathrm{~b}$ & $121.12(0.0001)$ \\
\hline
\end{tabular}

${ }^{a}$ Mean values followed by the same letter within rows do not differ significantly by the Student-Newman-Keuls test $(P=0.05)$.

${ }^{b}$ GI computed as the ratio between the percentage of adults emerged and the duration of the immature period (larval and pupal stages).

$0.0563 \mathrm{~g}$ for BRS 200 (Fig. 4). These results suggest that BRS Safira offers the best nutrition for A. argillacea development than the other cultivars, showing that a small leaf area consumed was capable of providing a faster larval development and heaviest pupae. According to Wier and Boethel (1995), the quality of the food is the main factor in determining insect food use.

Cultivars affected A. argillacea larval development: development was longer in BRS 200 (14.87 d) than in BRS Rubí (11.62 d) or Safira (11.14 d). Cotton genotypes significantly affect developmental time of $A$. argillacea larvae (Santos and Boiça 2001). They found that developmental time was longest when fed on cotton leaves from CNPA Precoce (14.7 d), 'CNPA Precoce 2 (14.4d), CNPA 9211-18 (14.3 d), and CNPA 9211-21 (14.4 d). However, Medeiros (2001) reported that the duration of the A. argillacea larval phase, when fed on cotton cultivar CNPA $7 \mathrm{H}$ leaves varied from $9.24 \mathrm{~d}\left(33^{\circ} \mathrm{C}\right)$ to $19.00 \mathrm{~d}\left(20^{\circ} \mathrm{C}\right)$. Santos et al. (2008) reported that larval development on 'BRS 201' (11.8 d), 'BRS Verde' (11.8 d), and 'Acala 90' (11.6 d) at $25^{\circ} \mathrm{C}$ had similar values to those given in this report.

Larval survival on BRS Safira (94.53\%) was similar to larval survival on BRS Rubí (94.53\%) and significantly lower on BRS 200 (79.50\%). Ferreira and Lara (1999) reported larval survival, depending on the cotton cultivar, ranging from 58 to $76 \%$ at $27^{\circ} \mathrm{C}$, whereas Santos and Boiça (2001) study has it highest survivorship on CNPA Precoce 1 (86.2\%) and CNPA 9211-29 (85.7\%) cotton leaves. The low survival rate of $A$. argillacea larvae is believed to be due to poor food quality (low quantities of water and nitrogen, high quantities of fiber and tannin content; Carvalho 1981) and other secondary chemistry, such as gossypol (Stipanovic et al. 2008).

Pupal weight was significantly higher when larvae fed on BRS Safira $(0.1340 \mathrm{~g})$ than those fed BRS Rubí $(0.0914 \mathrm{~g})$, and weight was significantly heavier than on BRS 200 (0.0563 g). An inflexible pupal size could be adaptive for species that have abundant but poor quality food sources such as low quantities of water and nitrogen and high quantities of fiber tannin content. In accordance with Mattson (1980), large larvae process low quality food more effectively and conserve water and energy better than small larvae. Plasticity in pupae weight could be advantageous for the insect when food is limited but of high quality. Therefore, larval stage duration, survival rate, as well as pupal weight were altered according to the cotton cultivar. Penna et al. (1989), Ferreira and Lara (1999), and Santos and Boiça (2001), reported that cotton genotypes affect pupal weight, survival and development of A. argillacea larvae. Although parameters such as oviposition and reproduction were not evaluated in our study, the pupal weight is positively related with the formation of healthy adults and consequently increases the number of eggs and fertility (Greenberg et al. 2001). In contrast, a reduction in pupal weight could bring a decrease in A. argillacea population density on cotton agroecosystems due to low egg viability (Santos et al. 2008). These results indicate that A. argillacea is best adapted to survive on BRS Safira. The high pupal weight and shorter larval period from this cultivar may be due in part to better digestion and food use. Food quality is the main factor that determines distribution, abundance, and food use for many plant-feeding insects (Waldbauer 1968), because the components of host plant directly effect the development, fecundity, and intake of plant feeders (Awmack and Leather 2002).

The feeding index (Fig. 4B) reflects plant biomass convertibility into insect body weight. This index was higher on BRS Safira than on BRS Rubí or BRS 200, indicating that higher amounts of BRS 200 must be consumed to produce a given pupal weight. The GI (Table 2) emphasizes the importance of food quality on survival and developmental time (Sétamou et al. 1999). Higher survival rates and shorter developmental times produced higher values of GI, indicating better food quality. The GI of BRS Safira was greater than that of BRS Rubí and BRS 200. These two indexes indicate that A. argillacea performed better BRS Safira and worse on BRS 200. Therefore, we conclude that BRS Safira provides the best food quality for A. argillacea, BRS 200 the worst, and BRS Rubí intermediate quality.

The A. argillacea's response to BRS 200 leaves could be associated to secondary metabolites produced by the host plant. Research has demonstrated that cotton cultivars produce certain secondary metabolites (Bottger and Patana 1966, Lukefahr et al. 1966) that enable the host plant to defend itself against severe phytophagous insect attacks. These chemical compounds interact with the insect's biology and behavior in a variety of ways, causing elevated mortality rates, lengthened larval phase, and lessened longevity and fertility (Pickett et al. 1999, Stipanovic et al. 2008). Gossypol, present in different parts of the cotton plant (McCarty et al. 1996), stands out among these secondary metabolites for inhibiting or deactivating acetylcholinesterase, produced in cholinergic neurons, causing disruptions in the central and peripheral nervous system 
of insects (Ryan and Byrne 1988). However, other chemical characteristics in the plant, such as nitrogen content (Boquet and Breitenbeck 2000), water, and carbohydrates can affect insect performance (Slansky and Scriber 1985), as well as physical characteristics, such as hardness and texture of leaf parenchyma. Leaves from BRS Safira are soft and less fibrous than those from BRS 200. The BRS 200 gene pool is partly composed of a lineage from the perennial cotton $G$. hirsutum variety marie Galante that has brown fiber; CNPA 92 1139, CNPA 94 362, and CNPA 95653 have fibrous and resistant leaves, whereas BRS Safira has soft leaves containing less fiber, and were produced from herbaceous cotton lineage.

Understanding the differences in food quality of cotton cultivars can have practical implications for $A$. argillacea management. When insects consume large parts of plants sprayed with insecticide, the dose of insecticide ingested per insect increases. BRS 200 provides low food quality and thus requires prolonged feeding in relation to BRS Safira and BRS Rubí. Consequentially, this increases the levels of leaf consumption and damage to the crop. However, this type of response is desirable for integrated pest management programs (Slansky 1990, Santos et al. 2008); the longer developmental times of A. argillacea on BRS 200 may allow longer windows of opportunity for the use of biological control agents (e.g., parasitoids, predators, and entomopathogens) (Clancy and Price 1987) to reduce the damage caused by this pest and also would complete fewer generations per phenological cycle of the cotton crop.

\section{Acknowledgments}

We express our appreciation to two anonymous experts for critical reviews of this manuscript. This work was supported by the Brazilian agencies Financiadora de Estudos e Projetos (FINEP) and Conselho Nacional de Desenvolvimento Científico e Tecnológico (CNPq).

\section{References Cited}

Awmack, C. S., and S. R. Leather. 2002. Host plant quality and fecundity in herbivorous insects. Annu. Rev. Entomol. 47: 817-844.

Bottger, G. T., and R. Patana. 1966. Growth, development, and survival of certain Lepidoptera fed gossypol in the diet. J. Econ. Entomol. 59: 1166-1168.

Boquet, D. J., and G. A. Breitenbeck. 2000. Nitrogen rate effect on partitioning of nitrogen and dry matter in cotton. Agron. J. 40: 1685-1693.

Carvalho, S. M. 1981. Biologia e nutrição quantitativa de Alabama argillacea (Hübner, 1818) (Lepidóptera: Noctuidae) em três cultivares de algodoeiro. Dissertação, ESALQ/USP, Piracicaba, SP, Brazil.

Clancy, K. M., and P. W. Price. 1987. Rapid herbivore growth enhances enemy attack: sublethal plant defenses remain a paradox. Ecology 68: 733-737.

Ferreira, A., and F. M. Lara. 1999. Tipos de resistência a Alabama argillacea (Hübner, 1818) (Lepidoptera: Noctuidae) envolvidos em genótipos de algodoeiro: II antibiose. Bragantia 2: 287-292.
Greenberg, S. M., T. W. Sappington, B. C. Legaspi Junior, T.X. Liu, and M. Sétamou. 2001. Feeding and life history of Spodoptera exigua (Lepidoptera: Noctuidae) on different host plants. Ann. Entomol. Soc. Am. 4: 566-575.

Horstmann, G. 1995. Dyeing as a new environmental challenge. J. Soc. Dyers Col. 111: 182-184.

Hsiao, T. H., and G. Fraenkel. 1968. Selection and specificity of the colorado potato beetle for solanaceous and nonsolanaceous plants. Ann. Entomol. Soc. Am. 61: 493503.

Littell, R. C., G. A. Milliken, W. W. Stoup, and R. D. Wolfinger. 1997. SAS system for mixed models. SAS Institute, Cary, NC.

Lukefahr, M. J., W. Noble, and J. E. Houghtaling. 1966. Growth and infestation of bollworms and other insects on glanded and glandless strains of cotton. J. Econ. Entomol. 59: 817-820.

Marchini, L. C. 1976. Avaliação de dano do curuquerê do algodão Alabama argillacea (Hübner, 1818) (Lepidoptera: Noctuidae) em condições similares e redução de sua população através de iscas tóxicas. Dissertação de Mestrado, ESALQ-USP, Piracicaba, SP, Brazil.

Mattson, W. J. 1980. Herbivory in relation to plant nitrogen content. Annu. Rev. Ecol. Syst. 11: 119-161.

McCarty, J. C., P. A. Hedin, and R. D. Stipanovic. 1996. Gossypium hirsutum spp. plant gossypol contents of selected GL2 and GL3 alleles. J. Agric. Food Chem. 44: 613-616.

Medeiros, R. S. 2001. Influência da temperatura no deesenvolvimento e na reprodução de Podisus nigrispinus (Heteroptera: Pentatomidae e no desenvolvimento de sua presa, Alabama argillacea (Lepidoptera: Noctuidae). Dissertação de Mestrado, UFV, Viçosa, MG, Brazil.

Montandon, R., H. J. Williams, W. L. Sterling, R. D. Stipanovic, and S. B. Vinson. 1986. Comparision of the development of Alabama argillacea (Hübner) and Heliothis virescens (F.) (Lepidoptera: Noctuidae) fed glanded and glandless cotton leaves. Environ. Entomol. 15: 128-131.

Parrot, W. L., J. N. Jenkins, and J. C. McCarty. 1983. Feeding behavior of first-stage tobacco budworm (Lepidoptera: Noctuidae) on three cotton cultivars. Ann. Entomol. Soc. Am. 76: 167-170.

Penna, J.C.V., J. Fallieri, and L. Ferreira. 1989. Avaliação de 15 raças primitivas de algodoeiro quanto a antibiose ao curuquerê. Pesqui Agropecu Bras. 8: 1033-1036.

Pickett, J. A., D.W.M. Smiley, and C. M. Woodcock. 1999. Secondary metabolites in plant-insect interactions: dynamic systems of induced and adaptive responses. Adv. Bot. Res. 30: 91-115.

Ramalho, F. S. 1994. Cotton pest management: part 4. A Brazilian perspective. Annu. Rev. Entomol. 39: 563-578.

Ryan, M. F., and O. Byrne. 1988. Plant-insect coevolution and inhibition of acetylcholinesterase. J. Chem. Ecol. 14: 1665-1975.

Santos, R. B., J. B. Torres, and C. S. Bastos. 2008. Densidade e crescimento populacional de Alabama argillacea em algodoeiro de fibra branca e colorida. Pesqui Agropecu Bras. 43: 457-463.

Santos, T. M., and A. Boiça, Jr. 2001. Resistência de genótipos de algodoeiro (Gossypium hirsutum L.) Alabama argillacea (Hübner) (Lepidoptera: Noctuidae). Neotrop. Entomol. 2: 297-303.

Saeed, S., A. H. Sayyed, and I. Ahmad. 2010. Effect of host plant on life-history traits of Spodoptera exigua (Lepidoptera: Noctuidae). J. Pest Sci. 83: 165-172.

SAS Institute. 2006. SAS/STAT user's guide. SAS Institute, Cary, NC. 
Scriber, J. M., and F. Slansky, Jr. 1981. The nutritional ecology of immature insects. Annu. Rev. Entomol. 26: 183211

Sétamou, M., F. Schulthess, N. A. Bosque-Pérez, H. M. Poehling, and C. Borgemeister. 1999. Bionomics of Mussidia nigricenella (Lepidoptera: Pyralidae) on three host plants. Bull. Entomol. Res. 89: 465-471.

Slansky, F., Jr. 1990. Insect nutritional ecology as a basis for studying host plant resistance. Fla. Entomol. 73: 359-378.

Slansky, F., Jr., and J. M. Scriber. 1985. Food consumption and utilization, pp. 165-211. In G. A. Kerkut and L. I. Gilbert (eds.), Comprehensive insect physiology, biochemistry, and pharmacology. Pergamon, London, United Kingdom.

Stipanovic, R. D., J. D. López, M. K. Dowd, L. S. Pucklaber, and S. E. Duke. 2008. Effect of racemic, $(+)$ - and (-)- gossypol on survival and development of Heliothis virescens larvae. Environ. Entomol. 37: 1081-1085.

Waldbauer, G. P. 1968. The consumption and utilization of food by insects. Adv. Insect Physiol. 5: 229-288.

Wier, A. T., and D. J. Boethel. 1995. Foliage consumption and larval development of three noctuid pests on soybean and cotton. J. Entomol. Sci. 30: 359-361.

Yamamoto, R. T., and G. Fraenkel. 1960. The physiological basis for the selection of plants for egg-laying in the tobacco hornworm, Protoparce sexta (Johan.), pp. 127133, vol. 3. In Proceedings of the 11th International Congress of Entomology, 17-25 August Vienna, Austria.

Received 9 December 2010; accepted 28 March 2011. 